\title{
Wheatgrass: A Natural and Holistic Medicine for Generation
}

\section{Shashikiran Hingade ${ }^{1 *}$ and Sharda Patekar ${ }^{2}$}

${ }^{1}$ Food Microbiology and Safety, College of Food Technology, Vasantrao Naik Marathwada Krishi Vidyapeeth, India ${ }^{2}$ Assistant Professor, Department of Food Process Technology, Sau. KSK 'Kaku' College of Food Technology, India

*Corresponding Author: Shashikiran Hingade, Food Microbiology and Safety, College of Food Technology, Vasantrao Naik Marathwada Krishi Vidyapeeth, India.

Received: October 14, 2019; Published: November 04, 2019

DOI: $10.31080 /$ ASNH.2019.03.0526

Wheat grass is a nutritionally complete food which will sustain the growth and development of human body. Wheat is used as a Staple food in all over India, that's may be the reason that wheat is known as king of all food grains.

"Wheat grass is the freshly sprouted first leaves of the common wheat plant, used as food, drink or dietary supplements".

Wheatgrass is served as fresh juice even it is often available as juice bar or tablets and are made for dried powder.

A Scientist called Ann wigmore was also a strong advocate for consumption of wheat grass as a part of raw food diet. he believed that wheatgrass, as a part of raw food diets, would cleans the body of toxins while providing a proper balance of nutrients as a whole food.

Wigmore was the founder of the hippoctrates health institute. She discovered the powerful healing properties of wheatgrass juice - "the richest nutritional liquid known to man".

\section{Wheatgrass nutraceutical components}

Like most of plants wheatgrass contain chlorophyll as one of most important valuable compounds, 17 amino acid, minerals, vitamins - A, B- complex, C, E and K. and enzymes. health benefits of wheatgrass range from providing supplemental Nutrition to having unique creative properties. wheatgrass is also a gluten free raw food diet because it is cuted before the grain forms.

\begin{tabular}{|c|c|}
\hline Nutrients & Wheatgrass juice \\
\hline Protein & $860 \mathrm{Mg}$ \\
\hline Beta - carotene & $120 \mathrm{IU}$ \\
\hline Vitamin E & $880 \mathrm{mcg}$ \\
\hline Vitamin C & $1 \mathrm{mg}$ \\
\hline Vitamin $\mathrm{B}_{12}$ & $0.30 \mathrm{mcg}$ \\
\hline Phosphorus & $21 \mathrm{mg}$ \\
\hline Magnesium & $8 \mathrm{mg}$ \\
\hline Calcium & $7.2 \mathrm{mg}$ \\
\hline Iron & $0.66 \mathrm{mg}$ \\
\hline Potassium & $42 \mathrm{mg}$ \\
\hline
\end{tabular}

Table
The nutrient content of wheatgrass juice is roughly equivalent to that of dark leafy vegetables.

\section{Wheatgrass juice}

Take a good quality wheat grains and soaked in water to initiates germination.

Fill a tray of $16 \times 16$ inches with soil and spread the grains by lightly pressing seeds into the soil then water the tray likely to moisten the content. after 6-8 days of growth harvest the grass with mature shoots.

1. Take fresh leafy wheatgrass cut into pieces and add enough water to blend in mixture or grinder.

2. Blend the wheat grass a water to just long enough to liquefy.

3. Pour into fine mesh strainer set over a clean glass.

4. Take this nutritionally rich juice at early in the morning. It takes away many health problems.

It is especially good for athletes because it is a juice which is a quick energy source and is assimilated in $20 \mathrm{~min}$ or less and uses very little the body's energy to extract the nutrients.

\section{Wheatgrass powder}

1. To prepare healthy wheatgrass Powder harvest the grass by trimming about $1 / 2$ an inch above the soil.

2. Wash it thoroughly in water to remove the soil particles.

3. The wheatgrass is placed on a baking tray to dry out of at 120-1500 degree for about an hour until it feeds dry brittle to the touch or even this can be sun-dried on a clean cloth but it will require 7-8 days to become dry brittle.

4. Grind the all dried wheatgrass in mixer grinder to make fine powder.

5. Sieving is done to remove the remained threads or fibres. 
6. Store it in proper contains and takes daily 1 to 2 tablespoon slightly worm water for better nutrition.

7. Store the Powder in airtight container.

Wheatgrass has so many amazing healthy benefits, and in powder form its easy to use on a daily basis for skin care, anaemia, blood cell, cancer fighting, $\mathrm{pH}$ balance and so much more. As a daily nutritional supplement and " environmental-hazard nutralizer" it is recommended that 1-2 ounces per day taken on an empty stomach, preferably before meal provides good benefits.

Some health benefits of wheat grass

1. The extensive combination of vitamins and minerals may make wheatgrass as complete nourishment.

2. The nutrients in wheatgrass aid the body in getting rid of impurities and stored toxins that chlorophyll in wheatgrass aids in detoxing the body.

3. It has high level of enzymes that aids in digestion and absorbs nutrients and may also help relieve from constipation and other digestive issue.

4. Wheatgrass is also known to lower cholesterol levels.

5. Wheatgrass enhance the functions of your immune system.

6. Wheatgrass has been shown to improve blood sugar level in people with diabetes. the compound in Wheatgrass has similar effect as insulin, which has positive effect on blood sugar level.

7. The chlorophyll molecule in Wheatgrass is similar to haemoglobin and increase blood cells count this may help to normalise the blood pressure And improve the circulation.

Volume 3 Issue 12 December 2019

(C) All rights are reserved by Shashikiran Hingade and Sharda Patekar. 